\title{
Generation Y and e-Learning: Study of the Impact of the Integration of the HP-Life Platform in Higher Education
}

\author{
Dkhili Sahbi and Boujdaria Mohamed Mahdi
}

\begin{abstract}
The general problem in which our research fits is about the innovation in the teaching practices at the University.

This study is rooted in the context of the establishment of higher education, the ISET (Higher Institute of Technological Studies) of Kairouan (Tunisia), through actions of integration of the HP-life platform in a program of e-learning in the teaching of various modules.

This integration implicates the study of its performance in the light of the involved actors, namely the learners (students).

The first part of this article exposes the state of the art of the evolution of the digital and remote education in the university, as well as on the emergence of the Generation Y. The second part presents the case of the ISET of Kairouan through the results of a questionnaire, administered to 120 students, to the answers on their own use of the Platform of e-learning HP-life.
\end{abstract}

Index Terms-E-Learning, generation Y, learning, higher education, HP-life platform.

\section{INTRODUCTION}

The emergence of information and communication technologies has, widely, upset at the same time the economic, technological environment and even that of the learning. Of the fact, these technologies are increasingly used as a new device for training and education, which has resulted, accordingly, to a new form of distance education, recognized by the e-learning.

The intensive use of the digital communications tools by the young people, named, therefore, Generation Y, exceeds the simple notions of fashion and punctually comfort, to transform into life style.

It is for that reason, the actors of the higher education have to consider this new need in information and communication technologies for the Generation Y, and to incorporate, so, these new tools of learning, into the education training and training of the students, in order to motivate them and boost their knowledge as well as necessary skills, adapted to the net economy.

The e-learning revises, therefore, the traditional modalities of learning and pushes, even, the established educational practices.

On the fact, both technological and educational innovation are manifested in the integration of the e-learning, particularly the HP-life platform that is teaching at the ISET of Kairouan, several questions can be asked to study and

Manuscript received May 23, 2017; revised August 12, 2017.

Sahbi Dkhili is with the Institut supérieur des études technologiques de Kairouan, Tunisia (e-mail: dkhilisahbi@yahoo.fr).

Boujdaria Mohamed Mahdi was with Institut supérieur des études technologiques de Kairouan, Tunisia (e-mail: meriameya@yahoo.fr). measure its impact on the learning of students.

Do the students feel the need for a training, only, online? Or do they prefer a mixed training?

Do the students use easily, as known by the Generation Y, the information and communication technologies? Alternatively, do they find problems of adaptation with the techno-pedagogies?

What are the effects of the integration of the e-learning on the learning of students?

Are the students satisfied with the program of HP-life?

Therefore, to answer these various questions, we chose to collect the perceptions of students, who use the HP-life platform as a tool for e-learning, through a questionnaire.

\section{THEORETICAL FRAMEWORK}

\section{A. The "e-Learning"}

\section{1) Definitions}

The definitions of the e-learning are diverse and varied, for example, that proposed by the European Commission, [1]: "Use of new multimedia technologies and the Internet to improve the quality of learning by facilitating the access to resources and services as well as remote exchanges and collaboration".

According to BENRAOUANE. S.A [2], the e-learning is an English term that means "learning by electronic ways". It refers to the use of web and new technological applications of distributed learning to improve the process of acquisition of a new knowledge or the update of new knowledge. The e-learning is used in the programs of national education, higher education, training of the company, and continuous training.

According to M, ally, [3], the e-learning refers to the use of the Internet to reach educational resources, teachers, other learners and media, during a learning process to acquire knowledge, skills or experience.

\section{2) The forms of the e-learning}

Although the e learning mainly designed to facilitate distance education, was may be exist even if the training or face-to-face. According to, Romiszowski, A., [4], there are several possibilities of combination between face to face and distance training with the use of e-learning.

Of the fact, we can distinguish, usually, three forms of e-learning:

Synchronous: Training in synchronous mode: real platforms time and system of "virtual class".

Therefore, it is a method of distance learning with a direct and immediate communication. For example via Skype, Chat or a video-conferences system on the Internet which brings 
together learners and trainers in a "virtual class", where they realize together the educational tasks (that Brigitte Albero and Philippe CHARIGNON, called the "e-Pedagogy [5]): explanations, questions and answers, exercises, simulations, research information, assessment.

Asynchronous (or off line training): Training in asynchronous mode.

Trainers and students communicates via the platform, but not necessarily at the same time. Thus, the exchanges between the trainer and the learner are made in a deferred way. In fact, the learner connect to the training server and works at its own pace; he is assisted by a guardian who, by e-mail, via a forum, guide him in his program and help him to achieve his tasks.

In consequent, two events are called synchronous, when they take place at the same time and asynchronous when they occur at two different times.

\section{a) Hybrid (blended learning)}

It is a method of mixed learning between courses in a face-to-face and remote on line. Thanks to this method, we can enrich and complete of classic training by offering online content. Of The fact, the online individual training is combined with working sessions in "classroom", with the trainers and other learners, to share experiences, achieve the work of the group, make role-playing games, and deepen the relational aspects of the training. [6]

In fact, some individuals need interaction in a group or a support for their learning; therefore, it will be necessary to add hybrids training so that they will have the possibility of practicing the theory and to ask any questions.

To choose the use or the establishment of one of these methods, it is necessary, from the beginning, to set the goals to achieve the knowledge and skills to be acquire and the type of e-learning (synchronous, asynchronous or blended).

To set up a mixed e-learning training or blended learning, it is required to decide which parts of the module will be teach online, and which will be handle during the training courses in face to face.

\section{3) The benefits of the e-learning}

Many studies ([7]-[9]]) show that the e-learning has positive effects on the learning.

One of the most recent studies on the quality of the e-learning, is the study led by the researchers Means, Toyama Murphy, Baki, and Jones, [7]. In this Meta study analysis, the researchers have reviewed the whole of the literature produced by the empirical surveys, which have focused on the phenomenon of online education in the USA between 1996 and 2008. Their objective is to know the degree of quality of online education, compared to face-to-face teaching, and whether the on-line teaching enriches better the face-to-face learning.

Four constants are putted forward:

- The performance of students on line is better than that of the students of face-to-face teaching. This constant concerns students of license, post-graduation, ongoing training, and vocational training;

- The hybrid learning (blended learning) which combines on line education with face-to-face learning, has more advantage than the purely learning classroom, or purely online;

- Online Education created a positive effect on the motivation and the involvement of the Learner because it allows him to exercise a control on the interactivity which binds to learning objects;

- Online education facilitates better the expansion of learning.

The importance of this Meta study analysis is to have settled in the debate on the advantages of e-learning. The online learning, or more particularly the blended learning, when it is well designed, he produced more positive effects on learning.

According to this study, the difference in the quality between the e-learning and the classical education lies not in the technology itself, but in the fact that the on-line apprenticeship exposes more the student to learning. The online courses request generally more time, require more preparation that is educational and oblige the learner to more collaboration. This situation amplifies the volume of work, adds to the task of the learning and it is well translated by better results.

On its side, Clark [9], has shown that the increase in the attention on a new device of training has a positive impact on the effort that provide the participants, effort which in turn has an effect on the performance of students

Although the conclusions drawn from these analyzes are little clear, because the information provided by the different educational institutions are partial; in general, studies show that "the e-learning is at least more effective than the classroom» [10]

\section{B. Generation $Y$}

\section{1) Genesis and definition}

The term "Generation Y" was first coined in 1993 by the American magazine Ad Age.

The Generation $\mathrm{Y}$ is known as the following designations: "Internet generation ", "Millennials", "EchoBoomers", "Nexters" and "Generation We", "yers", " Internet generation", "E-generation", "Net generation», «digital natives" ([11]-[14]).

Generally, the number of definitions used to designate "Young People" is disconcerting. All in all, there are more than 70 qualifiers used to qualify this generation [15].

According to Rémi Grégoire [16]. "The Generation Y designates the people born between 1978 and 1995. [...] This generation, which has grown up with the computer, Internet and the new technologies, is characterized by the constant search for novelty and personal development, a certain impatience, the hostility to the traditional forms of hierarchy, the desire to progress quickly, the desire to stand out and the envy to reconcile work, personal life and citizen commitment.

\section{2) The history and the particularities of different generations}

Every generation is a reflection of the historic phase in which she lived there. The inventions, the new technologies, the political and economic crises are phenomena which manage and influence the characteristics, the behaviors and the values that will be carried by a generation. 
Of the fact, specialists, as Julien Pouget [17], Strauss \& Howe [18], Cécile Déjoux \& Heidi Wechtler [19], tried to study the characteristics of different generations in order to understand how they progressed in their work environment and how they used new technologies and e-learning.

According to these authors, the cycle of generation crossed through four phases or four types.

Les quatre grandes générations du $\mathrm{XX}^{\mathrm{eme}}$ siècle $^{1}$

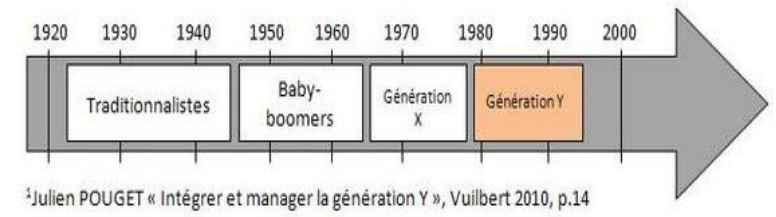

Fig. 1. Four big generations of the XX century [17].

\section{a) The "Veterans"}

Also called traditionalist Generation or Silent Generation) are born between 1920 and 1945. They knew the Second World War and the Great Depression. Their attitude is marked by the obedience and the respect for the Authority. They worked under modes of hierarchical management formal. Today some are still in charge of family businesses.

This generation, is often anti-technologies, and very attached to the traditional model of learning, and consequently it is very reluctant to any kind of online learning by the e-learning

\section{b) The "Baby-Boomers"}

Born between 1945 and 1965, represent the generation which knew periods of great economic prosperity and who benefited from the growth and from the full employment. It is this generation, which invented the consumer society and believes in the social success. It is loyal to the company and the hierarchy while advocating the individual autonomy. They have values such as the optimism, the team spirit, the research for professional success, the health and well-being, the personal growth, the youth, the work and the commitment ([20]); This group hand gradually to retirement.

Despite, it has lived the first booms of the computing, this generation stay remains, as well as that of the veterans, less attached to the technological progress, by a low use of information and communication technologies and a resistance toward any new modality of digital apprenticeship in e-learning.

\section{c) The "Generation X"}

Born between 1965 and 1977, was marked by the economic crisis, the collapse of the values and the technological shock. This population has developed a certain skepticism toward the future and organizations. They have "needs for independence, for autonomy and for control of the time which show themselves in their expectations in front of work, in particular by a marked entrepreneurial spirit, a strong implication in the resolution of problems, but also by a lower loyalty to their organizations and managers" ([21]). It is the generation currently in power.

This generation, has discovered the first creations and evolution of information and communication technologies, however their use rest medium, and in fact, it is very faithful to the methods of traditional learning.

\section{d) The "Generation Y"}

Born between 1978 and 1995, with globalization and the information technologies, these young people evolved in a context significantly different from that of the previous generations. In fact, the technological revolution and the arrival of new communication tools have enabled them to acquire a control almost intuitive of computing tools and an opening on the world with a permanent access and snapshot to the information. In effect, they would sacrifice the time of TV to create blogs or share their ideas on social media. They master the computing tool with a disconcerting ease, and consider the net as their natural environment. The fact, they want to be all the time connected; they contribute, cooperate and share information regularly.

The young people, who are derived, are for a wide share born in the digital era and make a massive use of the Internet in all aspects of their professional and daily lives. Qualified of digital natives by Marc Prensky [12], these children of the Internet behave differently from their elders, the digital immigrants for which the entry in the era of digital is a major upheaval.

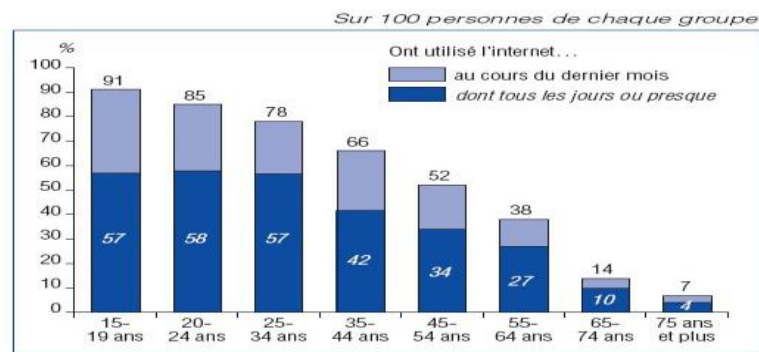

Fig. 2. Use of the Internet for personal purposes according to the age [21]

\section{3) The characteristics of the Generation $Y$}

Many authors ([22]-[24]) are arrested on its characteristics in focusing on attitudes and to the psychological aspect ([25] and [26]) or to the profiles of careers and professional aspirations ([27] and [28]).

The descriptions agree to define this generation around some striking features. We are interested here in particular to the characteristics of the Generation Y, who enroll in two main axes that are their preferences or styles of work, and on the other hand, their report to the technologies.

According to Joëlle Demougeot-Lebel, [29], the members of the Generation $Y$ would have preferences or working styles, which are appropriate for them, and they would seek or encourage:

- The research for Meaning At Work (why I should do it?) and the need for achievement;

- The collaborative work by reason of the team spirit that characterizes them and their willingness of social interactions based on relations of quality, confidence;

- The freedom of expression the equality of opportunity and tolerance;

- The members of the Generation $Y$ would have a high degree of familiarization with the technologies of information and communication and possess the knowledge and skills sophisticated in the field. They are characterized by a mode innovative communication and 
interactive. In fact, it is the first generation who grew up with technological innovations in continuous that it introduced in all its communication activities (Internet, emails, mobile phones, Skype...), research of informational content, playful or artistic (Google, Google Books, Wikipedia, YouTube...), of social networks (Facebook, Myspace, twitter...) or virtual (Second Life, World of Warcraft...).

\section{4) The generation $Y$ and the e-learning}

Nowadays, thus the educational modality is not to be, anymore envisaged in the same way as previously. In fact, the criteria of training of the new generation $\mathrm{Y}$ are not the same as that of their histories. The training is done, in a period or in another one, inevitably, remotely by the method of e-learning. Their constant connection to the net, to the search engines, to the online free encyclopedias and to the blogs of all kinds, make of them warned and convinced learners that a single source of knowledge will not be enough for them.

The social networks play a major role for this generation. A classic online environment tends not to be effective than online interactive tools where the students can share their courses and their experiences with the other learners.

Generally, the generation Y communicates more on-line than with direct contacts. The good strategy to be sure(safe) that they will continue their courses and to keep them to connect to the contents and to maintain a fresh news, this will encourage them to add their program of online court course on MSN, Facebook and other types of social networks. They need to be able to study from anywhere.

Generally, the generation Y communicates more on-line than with direct contacts. The good strategy to be sure(safe) that they will continue their courses and to keep them to connect to the contents and to maintain a fresh news, this will encourage them to add their program of online court course on MSN, Facebook and other types of social networks. They need to be able to study from anywhere.

Finally, it appears that to teach the generation $\mathrm{Y}$, it is necessary, first of all to understand them, to use their same technological tools, to allow them to work where they want and when they want and also to use the learning(apprenticeship) by the heap, that is to let them have a practice at the risk of making mistakes.

\section{Platform for e-Learning}

\section{1) Definition}

The CTIC, [30] defines the digital platforms as follows: it is discreet ecosystems of units of storage, computing codes and devices that, together, facilitate the public share of digital contents of a supplier towards many consumers or many consumers towards many consumers using the Internet protocol

The access to an e-learning training is made by means of a Web browser via a platform. The latter allows managing the accesses, to organize databases, to standardize the interfaces of presentation of the courses and the communication.

There are approximately more than 200 platforms of electronic learning of which around thirty under free licenses. Among platforms the most recognized in the world of the e-learning we quote for example [31]:
- Plei@d: is a pedagogical platform used by public administrations and essentially in higher education and professional training.

- Claroline: is a platform for online learning and of collaborative work. It allows you to hundreds of institutions throughout the world (universities, schools, and associations, companies...) to create and administer training and spaces of online collaboration.

- Elgg: designed initially for portfolios of learning at the University of Brighton, then widened in uses that are more general. Elgg is used in a pedagogical framework by several universities, including Canadian, French and US.

- Moodle: is a learning platform online under open source license used to create communities of learners around content and educational activities.

- HP-life: which is the case treaty in our research. The HPlife platform e-learning, with free access, contains courses in management, commerce, computer science and other areas, intended for learners.

As well, the e-learning by the platform, uses information and communication technologies for the online training. The goals are, for example, to apply, either free of charge or against payment, to a distance training by becoming identified on a platform through an Internet connection on a browser. Once registered, the person may begin its e-learning training.

2) HP-life platform (initiative learning for entrepreneurs) [32]

Within the framework of its citizens' actions, HP has set up a program of training and accompaniment in entrepreneurship called "HP-life", to support the students, the aspiring entrepreneurs as well as those already installed, to acquire skills in the field of business and of information and communication technologies in order to create or develop their own business.

This program has been implemented in Tunisia by UNIDO" United Nations Industrial Development Organization" in partnership with the API. The sessions of training and accompaniment in entrepreneurship HP-life in the various regions of Tunisia. A hundred entrepreneurs have benefited from the program to this day

The HP platform life e-learning includes courses in management, commerce, computer science and other areas.

Each of these courses is structured in five parts:

- Start

- History

- Commercial concepts:

- Technological concepts

- Discussion about the course

- Course evaluations

- Certification

\section{3) The objectives covered by the HP-LIFE platform}

The HP-life platform allows us to develop the different objectives of the training:

- Develop the intellectual curiosity of the students;

- Encourage the autonomy of students: promote the learning outside of the classroom;

- Diversify the sources of information and the formats (text, 
audio, video, image), while keeping a coherent link with the course;

- Promote the differentiated pedagogy ;

- Encourage the participation of students (in particular those who do not participate much in class);
- Promote the "digital elimination of illiteracy" in the students

- Use as a system of online evaluation where we can visualize global or individual results.

TABLE I: COURSES OF THE HP-LIFE PLATFORM [32]

\begin{tabular}{|c|c|c|c|c|}
\hline Finance & Marketing & The operations & Communications & Special topics \\
\hline Fundamental of the finance & $\begin{array}{c}\text { Marketing } \\
\text { On the social networks }\end{array}$ & Optimize the capacities & Your target audience & $\begin{array}{c}\text { Creation of a } \\
\text { Social Enterprise }\end{array}$ \\
\hline Profits and losses & $\begin{array}{c}\text { Unique } \\
\text { Value Proposition } \\
\end{array}$ & $\begin{array}{c}\text { Management of } \\
\text { contact information }\end{array}$ & Effective presentations & $\begin{array}{c}\text { Energy } \\
\text { efficiency: Do More with Less }\end{array}$ \\
\hline $\begin{array}{l}\text { Search for } \\
\text { financing }\end{array}$ & Sell online & Customer Relationship Management & Business email & Effective Leadership \\
\hline Anticipate sales & $\begin{array}{c}\text { Benefits } \\
\text { Against characteristics }\end{array}$ & Management of inventory & Effective websites & \\
\hline
\end{tabular}

\section{EMPIRICAL FRAMEWORK: A MEASURE OF THE IMPACT OF THE PROGRAM HP-LIFE ON THE LEARNING OF THE STUDENT}

\section{A. Research Objectives}

- Measure the impact of the HP program life on the development of knowledge;

- Measure the impact of the HP program life on the development of the know-how;

- Measure the satisfaction to the HP-LIFE program.

\section{RESEARCH HYPOTHESES}

- Hypothesis 1: The students interviewed belongs to the Generation Y.

- Hypothesis 2: The students feel the need for an online training.

- Hypothesis 3 : In relation to teaching in the ISET, students prefer a mixed training (face to face training and online);

- Hypothesis 4: The usefulness of the HP-life program depends on the department

- Hypothesis 5: As a result of the program, the students have developed the expertise more than the knowledge.

- Hypothesis 6: The development of the knowledge and expertise depends on the department.

- Hypothesis 7: The operation of the HP-life program depends on the department.

- Hypothesis 8: the students are globally satisfied with the HP-life program.

- Hypothesis 9: The program HP-life has a positive impact on the students.

\section{ReSEARCH Methodology}

The research hypotheses have been verified in a longitudinal with a group of 120 students in the third year of the Higher Institute of Technological Studies of Kairouan certified in the program HP-life e-learning.
To collect the data, a questionnaire has been distributed in class and analyzed from the SPSS software version 21 .

\section{1) Pre-test}

A first pre-test was done with the questionnaire. A printed version of the questionnaire was administered to a group of 10 students. This pre-test allowed making sure that the understanding of the various statements did not raise problems.

\section{2) Sampling method}

Probabilistic (simple random sampling). It is the reference model and the simplest to be used: all the individuals have the same probability to belong to the sample.

It is the case of our research, where very turn out to be difficult to study the whole of the population, namely, all students of the ISET of Kairouan. Of the fact, we have taken a representative sample of 120 students.

\section{3) Technical administration}

Face to face in the class. The objective of the choice of this method is of:

- Establish a preliminary contact with the interviewees to explain them purpose of the research, the type of questions that will be posed, the role and the number of interviewed and to verify if they are inclined to give information relevant

- Explain to the interviewed certain concepts or questions, which are ambiguous and poorly understood, and this so that they answer correctly and to avoid, so, biasing and falsifying, the results and, by consequence, our research generally.

\section{ANALYSIS OF RESULTS}

1) Hypothesis 1: Profile of Respondents

The following table presents the profile of the 120 students who responded to the questionnaire.

The hypothesis 1 is validated, because all of the students were born between 1978 and 1994: phase of the birth of the Generation Y. Thus, our sample is representative and composed, so, of persons (students) of the Generation $\mathrm{Y}$ 
TABLE II: PROFILE OF RESPONDENTS

\begin{tabular}{|c|c|}
\hline Ages & $\begin{array}{l}0 \%<1978 \\
100 \% 1978-1995 \\
0 \%>1995\end{array}$ \\
\hline Sex & $\begin{array}{l}47.5 \% \text { men } \\
52.5 \% \text { women }\end{array}$ \\
\hline Departments & $\begin{array}{l}25 \% \text { Economic Sciences and Managemen } \\
25 \% \text { Information Technology } \\
25 \% \text { Electrical Engineering } \\
25 \% \text { Mechanical engineering }\end{array}$ \\
\hline
\end{tabular}

2) Hypothesis 2

TABLE III: NEED TO USE THE E-LEARNING

\begin{tabular}{|c|c|c|c|c|c|}
\hline & & Staff & Percentage & $\begin{array}{c}\text { Valid } \\
\text { Percentage }\end{array}$ & $\begin{array}{l}\text { Cumulative } \\
\text { percentage }\end{array}$ \\
\hline \multirow{3}{*}{ Valid } & Yes & 119 & 99.2 & 99.2 & 99.2 \\
\hline & Non & 1 & .8 & .8 & 100.0 \\
\hline & Total & 120 & 100.0 & 100.0 & \\
\hline
\end{tabular}

By analyzing the results of the description of the variable "Need for online training" among students, we have been able to release that $99.2 \%$ of students feel the need to use the e-learning.

3) Hypothesis 3

TABLE IV: ONLINE TRAINING

\begin{tabular}{|rr|r|r|r|r|}
\hline & \multicolumn{1}{|c|}{ Staff } & Percentage & $\begin{array}{c}\text { Valid } \\
\text { Percentage }\end{array}$ & $\begin{array}{c}\text { Cumulative } \\
\text { percentage }\end{array}$ \\
\hline \multirow{3}{*}{ Valid } & Yes & 8 & 6.7 & 6.7 & 6.7 \\
& Non & 112 & 93.3 & 93.3 & 100.0 \\
& & & & \\
\hline
\end{tabular}

TABLE V: FACE-TO-FACE TRAINING

\begin{tabular}{|c|c|c|c|c|}
\hline & Staff & Percentage & $\begin{array}{c}\text { Valid } \\
\text { Percentage }\end{array}$ & $\begin{array}{l}\text { Cumulative } \\
\text { percentage }\end{array}$ \\
\hline Yes & 14 & 11.7 & 11.7 & 11.7 \\
\hline Non & 106 & 88.3 & 88.3 & 100.0 \\
\hline Total & 120 & 100.0 & 100.0 & \\
\hline
\end{tabular}

TABLE VI: MIXED TRAINING

\begin{tabular}{|rr|r|r|r|r|}
\hline & \multicolumn{1}{|c|}{ Staff } & Percentage & $\begin{array}{c}\text { Valid } \\
\text { Percentage }\end{array}$ & $\begin{array}{c}\text { Cumulative } \\
\text { percentage }\end{array}$ \\
\hline \multirow{3}{*}{ Valid } & Yes & 98 & 81.7 & 81.7 & 81.7 \\
& Non & 22 & 18.3 & 18.3 & 10 \\
& Total & 120 & 100.0 & 100.0 & \\
\hline
\end{tabular}

According to the tables above the variable "nature of the training to the ISET," we find that $81.7 \%$ of students prefer a mixed training, $6.7 \%$ prefer online training and $11.7 \%$ prefer a face-to-face training.

The hypotheses 2 and 3 are validated. Indeed, the students feel the need of online training and prefer a mixed training to the ISET. On the fact, those responsible for the educational and teachers should reflect to integrate more the e-learning into the education.

4) Hypothesis 4
The usefulness of the HP- life program depends on the department. Indeed the Asymptotic meaning is less than 0.05.

TABLE VII: HP-LIFE TRAINING/USEFUL ANOVA OF 1 FACTOR

\begin{tabular}{|l|r|r|r|r|}
\hline & Sum of squares & ddl & Mean Squares & F \\
\hline Inter-groups & 12.567 & 3 & 4,189 & 6,584 \\
Intra-groups & 73,800 & 116 &, 636 & \\
Total & 86,367 & 119 & & \\
\hline
\end{tabular}

The students of the Department of economic sciences and management consider that the HP- LIFE program is useful (average is equal to 3.68); while the students of the department of electrical engineering consider it unnecessary (average is equal to 2.23). This is explained by the perception of students who consider that the program is oriented more toward the discipline of management and trade.

\section{5) Hypothesis 5}

The HP-life program allows developing the expertise (technological skills) more than the knowledge (concepts) at the student. Indeed, $37 \%$ of the respondents declare they develop the knowledge while $61.7 \%$ report develop the expertise.

TABLE VIII: HP-LIFE TRAINING AND DEVELOPMENT OF KNOWLEDGE

\begin{tabular}{|l|r|r|r|r|}
\hline & Staff & Percentage & $\begin{array}{c}\text { Valid } \\
\text { Percentage }\end{array}$ & $\begin{array}{c}\text { Cumulative } \\
\text { percentage }\end{array}$ \\
\hline Not at all in & 15 & 12.5 & 12.5 & 12.5 \\
agreement & 11 & 9.2 & 9.2 & 21.7 \\
Not Agree & 58 & 48.3 & 48.3 & 70.0 \\
Malid & 31 & 25.8 & 25.8 & 95.8 \\
In Agreement & 5 & 4.2 & 4.2 & 100.0 \\
Totally agree & & & & \\
Total & 120 & 100.0 & 100.0 & \\
\hline
\end{tabular}

TABLE IX: HP-LIFE TRAINING AND DEVELOPMENT OF KNOW-HOW

\begin{tabular}{|l|r|r|r|r|}
\hline & Staff & Percentage & $\begin{array}{c}\text { Valid } \\
\text { Percentage }\end{array}$ & $\begin{array}{c}\text { Cumulative } \\
\text { percentage }\end{array}$ \\
\hline Not at all in & 3 & 2.5 & 2.5 & 2.5 \\
agreement & 3 & 2.5 & 2.5 & 5.0 \\
Not Agree & 40 & 33.3 & 33.3 & 38.3 \\
Moderately Agree & 45 & 37.5 & 37.5 & 75.8 \\
Valid & 29 & 24.2 & 24.2 & 100.0 \\
In Agreement & & & & \\
Totally agree & 120 & 100.0 & 100.0 & \\
Total & & & \\
\hline
\end{tabular}

6) Hypothesis 6

TABLE X: HP TRAINING LIFE/KNOWLEDGE DEVELOPMENT ANOVA TO 1 FACTOR

\begin{tabular}{|l|r|r|r|r|r|}
\hline & Sum of squares & ddl & Mean Squares & F & $\begin{array}{l}\text { Mea } \\
\text { ning }\end{array}$ \\
\hline Inter-groups & 45,667 & 3 & 15,222 & 23,132 & .000 \\
Intra-groups & 76,333 & 116 &, 658 & & \\
Total & 122,000 & 119 & & & \\
\hline
\end{tabular}

The development of knowledge depends on the department. Indeed, the asymptotic meaning is less than 0.05 .

The students how study economic sciences and management have developed more knowledge (average is equal to 3.60) while the students how study information 
technology have developed little knowledge (average is equal to 2.13).

TABLE XI: HP-LIFE TRAINING/DEVELOPMENT OF KNOW-HOW ANOVA OF 1 FACTOR

\begin{tabular}{|l|r|r|r|r|r|}
\hline & \multicolumn{1}{|c|}{$\begin{array}{c}\text { Sum of } \\
\text { squares }\end{array}$} & ddl & Mean Squares & F & Meaning \\
\hline Inter-groups & 20,833 & 3 & 6,944 & 9,880 & .000 \\
Intra-groups & 81,533 & 116 &, 703 & & \\
Total & 102,367 & 119 & & & \\
\hline
\end{tabular}

The development of the knowledge depends on the department. Indeed, the asymptotic meaning is less than 0.05 .

The students of mechanical department have developed more the know-do (average is equal to 4.36). This gives some explanation by the fact that within the framework of the course entrepreneurial culture III, we have asked the students to exploit the modules HP-life in the business plan of their project of creation.

7) Hypothesis 7

TABLE XII: TESTING THE KHI-TwO

\begin{tabular}{|l|r|r|r|}
\hline & Value & ddl & \multicolumn{2}{|c|}{$\begin{array}{c}\text { Asymptotic meaning } \\
\text { (bilateral) }\end{array}$} \\
\hline Khi-two of Pearson & $29,471 \mathrm{~h}$ & 3 & .000 \\
Likelihood ratio & 35,158 & 3 & .000 \\
Linear Association linear by & 21,926 & 1 & .000 \\
Number of valid observations & 120 & & \\
\hline
\end{tabular}

Zero cells $(0.0 \%)$ have a theoretical size less than 5 . The minimum theoretical size is 11.50 .

TABLE XIII: TESTS OF KHI-TwO

\begin{tabular}{|l|r|r|r|}
\hline \multicolumn{4}{|c|}{ TABLE XIII: TESTS OF KHI-TwO } \\
\hline Khi-two of Pearson & Value & ddl & Asymptotic meaning (bilateral) \\
Likelihood ratio & 24,480 ha & 3 & .000 \\
Linear Association & 32,053 & 3 & .000 \\
linear by &, 428 & 1 &, 513 \\
Number of valid & & & \\
observations & 120 & & \\
\hline
\end{tabular}

0 cells $(0.0 \%)$ have a theoretical size less than 5 . The minimum theoretical size is 5.00 .

TABLE XIV: TESTS OF KHI-TwO

\begin{tabular}{|l|r|r|r|}
\hline & Value & ddl & Asymptotic meaning (bilateral) \\
\hline Khi-two of Pearson & 40,411 ha & 3 & .000 \\
Likelihood ratio & 41,176 & 3 & .000 \\
Linear Association & 20,192 & 1 & .000 \\
linear by & & & \\
Number of valid & 120 & & \\
observations & & \\
\hline
\end{tabular}

0 cells $(0.0 \%)$ have a theoretical size less than 5 . The minimum theoretical size is 10.75 .

The exploitation of the HP-life program (Project of the end of study, courses and project) depends on the department. Indeed, the asymptotic meaning is less than 0.05 .

The students in Business Administration will exploit the HP-life program in the Project of the end of study (creation of company), while the students in the information technologies, electrical engineering and mechanical engineering will exploit the program in the projects.

8) Hypothesis 8
TABLE XV: STATISTICS

\begin{tabular}{|r|r|r|r|r|r|}
\hline & $\begin{array}{c}\text { HP- life } \\
\text { training } \\
\text { /useful }\end{array}$ & $\begin{array}{c}\text { HP- life } \\
\text { training } \\
\text { /easy to } \\
\text { understand }\end{array}$ & $\begin{array}{c}\text { HP- life } \\
\text { training } \\
\text { /easy to } \\
\text { implement }\end{array}$ & $\begin{array}{c}\text { HP -life } \\
\text { training } \\
\text { life/Motiva } \\
\text { ting }\end{array}$ & $\begin{array}{c}\text { HP- life } \\
\text { training } \\
\text { LIF/Fun }\end{array}$ \\
\hline $\mathrm{N} \quad \begin{array}{r}\text { Valid } \\
\text { Missing }\end{array}$ & 120 & 120 & 120 & 120 & 120 \\
Average & 3,2833 & 3,8917 & 3,6167 & 3,8917 & 3,7250 \\
\hline
\end{tabular}

By analyzing the results of the description of the variables of the satisfaction by report to the HP-life program, we were able to identify that the students think that the training is useful, easy to understand, easy to implement, motivating and funny.

Another very important factor, which explains the satisfaction of students, is that the program is free and certifying.

This result is justified by the statistics of the average of very variable which are all higher than 3 .

9) Hypothesis 9

TABLE XVI: SATISFIED WITH THE HP TRAINING

\begin{tabular}{|l|r|r|r|r|}
\hline & Staff & Percentage & $\begin{array}{c}\text { Valid } \\
\text { Percentage }\end{array}$ & $\begin{array}{c}\text { Cumulative } \\
\text { percentage }\end{array}$ \\
\hline Not Agree & 7 & 5.8 & 5.8 & 5.8 \\
Moderately & 19 & 15.8 & 15.8 & 21.6 \\
Va Agree & & & & 59.1 \\
lid In Agreement & 45 & 37.5 & 37.5 & 100.0 \\
Totally agree & 49 & 40.8 & 40.8 & \\
Total & 120 & 100.0 & 100.0 & \\
\hline
\end{tabular}

According to the analysis of the descriptive statistics, the majority $(78.3 \%)$ of the students are satisfied of the HP-life training.

\section{CONCLUSION}

Our article aims to exploit the answers around the effects of the use of the HP-life platform of online teaching in the establishment of the Higher Education ISET of Kairouan (Tunisia). To respond to the concern of this institution to develop its pedagogical practices, so that they are more in phase with the expectations of the employment market and in connection with the concern for the quality of teaching, we rely on the assumption that information and communication technologies can be considered as catalysts of pedagogical change, and that the students, supposed to belong to the Generation Y, master suitably these technologies.

Indeed, the young people of Generation $Y$, who grew up in the era of the information and of the Internet, appear to be prepared for the future. They work in a network and master the information and communication technologies better than all the previous generations. This allows them to access quickly the knowledge and to learn very easily, through distance education by the e-learning.

In fact, based on the survey of students, we concluded that the latter feel the need for online training by the platform of e-learning HP-life. In addition, they are satisfied by the communication capabilities and access to resources provided by the platform, and this in the light of the use of multitudes online educational resources and their potential of autonomy. They integrated, probably, the opportunities offered by a permanent connection and express their pleasure for this 
experience, eventually, a constant use in the framework of their student's activities. The e-learning is proving to be as well, for them, a particularly relevant tool for self-training and self-assessment.

Nevertheless, despite their great enthusiasm of the incorporation of the e-learning in their training, remains that most of the students prefer, rather, a mixed training.

Therefore, the tendency of students is oriented, generally, toward mixed solutions. In fact, efficiency is higher when information and communication technologies are used as a supplement to the traditional methods face to face. In addition, the interactivity allows the programming more profound and experiences more full in terms participative and reflexive terms.

Finally, the performance of a device of e-learning must not be reduced to the use of the HP-life platform in the teaching of subjects. However, it deserves, according to us, to include the ability of the institution to exploit the potential that represents a context of distance education to improve the quality of learning of students and to increase the chances of their employability in the labor market. Moreover, even take advantage of the benefits got by this program to train them to create their own employment by new business start-up.

\section{REFERENCES}

[1] Commission of the European Communities, "Rapport de la commission, les objectifs concrets futurs des systèmes d'éducation.Bruxelles," the 31.01.2001 COM, 2001.

[2] S. A. Benraouane, "Guide pratique du e-learning," Edition Dunod, Paris, 2011. pp. 2-11.

[3] M. Ally, "Foundation of educational: Theory for online learning," Theory and Practice of Online Learning, Athabasca AB, Athabasca University, Canada, 2004, pp. 3-31.

[4] A. Romiszowski, "The future of e-learning as an educational innovation factors influencing project success and failure," Brazilian Review of Open and Distance Education, September 2003.

[5] B. Albero and P. Charignon, "e e-pédagogie à l'université: moderniser l'enseignement ou enseigner autrement?" Edition EUAM, 2008.

[6] G. Valenduc and P. Vendramin, "L'apprentissage en ligne et la formation continue," La Lettre EMERIT $n^{\circ} 43$, Troisième trimestre 2005.

[7] B. Means et al., "Evaluation of evidence-based practices in online learning: A meta-analysis and review of online learning studies," the U.S. Department of Education, September 2010.

[8] L. Endrizzi, "Les technologies numériques dans l'enseignement supérieur," Dossier d'actualité, n 78 , octobre. Lyon: École normale supérieure de Lyon., 2012.

[9] R. E. Clark, "Évaluer l'enseignement à distance: Stratégies et avertissements," Distances et Savoirs, vol. 7, no. 4, 2009, pp. 93-112.

[10] F. Fenouillet and M. Déro, "Le e-learning est-il efficace?" Savoirs, no. 12 , pp. $87-100,2006$.

[11] S. P. Eisner, "Managing generation Y," SAM Advanced Management Journal, vol. 70, no. 4, pp. 4-15. 2005.

[12] M. Prensky, "Digital natives, digital immigrants," On the Horizon, MCB University Press, vol. 9, no. 5, October 2001.

[13] E. Greenberg and K. Weber, "Generation we: How millennial youth are taking over America and changing our world forever," PCHATUSAN, October 15, 2008.

[14] C. Jones and B. Shao, "The net generation and digital natives: Implications for higher education," A Literature Review Commissioned by the Higher Education Academy, 2011.

[15] D. Monneuse, "Les jeunes expliqués aux vieux," L'Harmattan, 2012
[16] R. Grégoire, "La Génération Y, génération apprenante, génération exigeante?" LE MAG DU NUMÉRIQUE5 MAR 2013.

[17] J. Pouget, "Intégrer et manager la génération Y," Vuibert P., p. 14, 2010.

[18] W. Strauss and N. Howe, "Generations: The history of America's future, 1584 to 2069," Harper Perennial, 1991.

[19] C. Déjoux and H. Wechtler, "Diversité générationnelle: implications, principes et outils de management," Management \& Avenir, 2011.

[20] T. SABA, "Les différences intergénérationnelles au travail: faire la part des choses," Revue internationale de gestion, no. 3, vol. 34, pp. 26-37, 2009.

[21] O. Donat. "Pratiques culturelles 2008, DEPS, ministère de la Culture et de la Communication," Culture et Etude, 2009.

[22] C. Glée et al., "Nouveaux comportements au travail et prospective du management: l'intégration paradoxale de la génération $\mathrm{Y}$ en entreprise," 10ème rencontre sur la prospective des métiers: Quel management demain ? Essec, Paris, 2010.

[23] C. A. Martin and B. Tulgan, "Managing the generation mix: from urgency to Opportunity," HDR Press, 2006.

[24] W. Strauss and N. Howe, "Millennials rising: The next great generation: Vintage," First Edition, 2000.

[25] J. M. Twenge and S. M. Campbell, "Generational differences in psychological traits and their impact on the workplace," Journal of Managerial Psychology, pp. 862-877, 2008.

[26] L. Coulon et al., "Generational differences in personality and motivation do they exist and what are the implications for the workplace?" Journal of Managerial Psychology, pp 878-890, 2008.

[27] N. Hess and D. M. Jepsen, "Career internship and generational differences in psychological contracts," Career Development International, pp 261-283. 2009.

[28] S. A. Hewlett et al., "How gen Y \& boomers will reshape your agenda," Harvard Business Review, pp. 71-76, 2009.

[29] D.-L. Joëlle, "Enseignants-chercheurs de la Génération Y: incidence sur les pratiques pédagogiques ?" Revue internationale de pédagogie de l'enseignement supérieur, 2014.

[30] ICTC-CTIC, "Étude du sous-secteur des plateformes numériques : Une analyse de la situation," Conseil des technologies de l'information et des communications, Ottawa, 2013

[31] Wikipedia. [Online]. Available: https://fr.wikipedia.org/wiki/

[32] HP platform-life. [Online]. Available: http://www.life-global.org

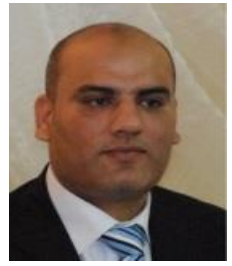

Dkhili Sahbi was born in 1975, in Kairouan, Tunisia $\mathrm{He}$ got the Diploma of Advanced Studies in Management, issued from the Faculty of Economic and Management Sciences of Tunis in 2003; the Master of Science in Management, issue from by the Faculty of Economic and Management Sciences of Tunis in 1999; the Bachelor's degree in Experimental Sciences. Secondary school IBN JAZZAR Kairouan in 1995. He taught management of the company, policy and strategy of the company, management control, system information, marketing, quality management system, management of production, statistical quality control, entrepreneurial culture, financial accounting, financial analysis. He is a Teacher Technologist at the Higher Institute of Technological Studies of Kairouan (Tunisia).

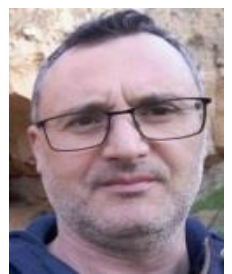

Boujdaria Mohamed Mahdi was born in 1974 in Kairouan, Tunisia. He got the MBA issued from University of Tokyo of foreign studies in 2005; the Master of Science in Management, issued from ISG Sousse in 1999; and the Bachelor's degree in Experimental Sciences. Secondary school IBN JAZZAR Kairouan in 1995. He is teacher technologist at the Higher Institute of Technological Studies of Kairouan (Tunisia). He taught Marketing, Quality Management System, Management of the company, Entrepreneurial culture, Method of resolution of problems. 